\title{
Synergetic Effect of $\alpha$-Lipoic Acid with Keratinocyte Growth Factor on Protecting Alveolar Epithelial Type II Cells of Rat Fetus from Hyperoxia -Induced Injury
}

\author{
Jing Wang ${ }^{\mathrm{a}}$ Wei Liu ${ }^{\mathrm{a}}$ Yang Peng ${ }^{\mathrm{a}}$ Wenbin Li Tingting Cheng Chunfang Gao \\ Luxia Mo Zhen Zhao Liwen Chang
}

Department of Pediatrics, Tongji Hospital, Tongji Medical College, Huazhong University of Science and Technology, Wuhan, China; ${ }^{a}$ All authors contributed equally to this work

\section{Key Words}

Keratinocyte growth factor $\bullet \alpha$-lipoic acid $•$ Alveolar epithelial type II cells $\bullet$ Hyperoxia-induced lung injury $\bullet$ Oxidative stress

\begin{abstract}
Aim: To explore the potential mechanism of the synergetic effect of $\alpha$-lipoic acid with keratinocyte growth factor (KGF) on protecting alveolar epithelial type II cells (ATIICs) from hyperoxia-induced injury. Methods: Primary culture of ATIICs from the Sprague-Dawley rat fetuses was examined under room air and $95 \%$ of $\mathrm{O}_{2}$. Various KGF concentrations (0 to 100 $\mathrm{ng} / \mathrm{mL}$ ) and $0.5 \mathrm{mM}$ of $\alpha$-lipoic were added into the cell culture. Levels of intracellular reactive oxygen species, necrosis, and proliferation of ATIICs were measured using flow cytometry, ELISA, and MTT assays, respectively. RT-PCR was performed to detect KGFR mRNA expression. Western blot was employed to detect the expression of KGFR, phospho-p53, HDAC1, and acetylated H3 and H4. Results: KGF promoted the proliferation and inhibited the apoptosis of ATIICs in room air or under temporary exposure to hyperoxia. However, the resistance of ATIICs to KGF was observed after prolonged exposure. Further investigation demonstrated that down-regulation of KGF receptor via activation of p53 and recruitment of HDAC1 induced by oxidative stress contributed to KGF resistance. This resistance could be attenuated by $\alpha$-lipoic acid, a powerful antioxidant. Conclusion: Application of KGF combined with $\alpha$-lipoic acid could inhibit KGF resistance to provide maximum protection to ATIICs from hyperoxic injury.
\end{abstract}

Copyright (c) 2014 S. Karger AG, Basel

\section{Introduction}

Oxygen therapy is one of the most important treatments for asphyxia resuscitation and preterm respiratory support in the delivery room and NICU. Inspiration of high concentration 


\section{Cellular Physiology and Biochemistry}

Cell Physiol Biochem 2014;33:953-966

Wang et al.: $\alpha$-LA Combined with KGF Protects Alveolar Epithelial Type II Cells from Hyperoxia-Induced Injury

of oxygen and/or prolonged postnatal exposure to hyperoxia results in oxidative stress-induced damage in multiple tissues and organs, such as acute lung injury (ALI), bronchopulmonary dysplasia and retinopathy of prematurity. Excessive reactive oxygen species (ROS) and less efficient intracellular antioxidant defense contributes to oxygen toxicity. ROS in the physiological level can directly interact with critical signaling molecules to initiate cellular signaling pathway and promote proliferation and differentiation. By contrast, increased ROS up to the pathological level can cause damage to cellular proteins, lipids, and DNA, which leads to cell apoptosis $[1,2]$. Preterm infants have lower antioxidant defense and are more susceptible to oxidative stress compared with term infants. Oxygen toxicity in the lung can result in the swelling of endothelial cells, loss of capillary endothelial cells, and abnormal appearance of mitochondria [3,4]. Prolonged exposure to hyperoxia after birth can diminish septation and alveolar angiogenesis, increase terminal respiratory tract volume, and promote pulmonary fibrosis, resulting in pulmonary hypoplasia.

Keratinocyte growth factor (KGF), also known as FGF-7, is a member of the fibroblast growth factor family. It is produced specifically by mesenchyme cells and exclusively binds onto a KGF receptor (KGFR) located on the surface of an epithelial cell through paracrine interactions. KGF was first isolated as an epithelial cell mitogen from the conditioned medium of the human embryonic lung fibroblast cell line [5]. KGF can promote proliferation and migration of keratinocyte $[6,7]$ and has an important function in healing wounds and repairing after injury [8-12]. In the lung, KGF can stimulate proliferation, inhibit apoptosis [13], repair damaged airway epithelium [14], dampen the response of epithelial cells to inflammatory mediators [15], and promote the maturation of fetal lung epithelium by increasing the synthesis of protein and phospholipid surfactant components [1618]. Previous investigations have shown that KGF expression is suppressed in early ALI/ ARDS [19]. Therefore, supplementation of exogenous KGF may be helpful before or after injury. Barazzone et al. [20] found that administration of high dose (total dose of $20 \mu \mathrm{g} / \mathrm{g}$ ) recombinant human KGF (rhKGF) i.v. to mice before 2- and 1-day oxygen exposure effectively attenuates alveolar damage than injection of rhKGF after oxygen exposure. Similar results was demonstrated by Panos [21]. However, Franco et al. [22] found that rat pups inspired with $95 \% \mathrm{O}_{2}$ were effectively protected from lung injury by intraperitoneal injection of lower dose $(2 \mu \mathrm{g} / \mathrm{g}) \mathrm{rhKGF}$ on days $1,3,5$, and 7 of oxygen expose. In addition, our preliminary study involving immediate intraperitoneal administration of rhKGF with $2 \mu \mathrm{g} / \mathrm{g}$ up to $20 \mu \mathrm{g} / \mathrm{g}$ after hyperoxic exposure provided no protection. Therefore, we speculate that decreased KGF sensitivity (KGF resistance) may occur in early oxidative stress leading to poor effect of immediate treatment after hyperoxic injury. Furthermore, KGFR down-regulation induced by oxidative stress may contribute to this process considering ligand-receptor relationship.

Alpha-lipoic acid ( $\alpha$-LA), also known as thioctic acid, was first isolated from bovine liver in 1951 [23]. Both $\alpha$-LA and its reduced form dihydrolipoic acid (DHLA) are ideal antioxidants with amphiphilic character, and they can easily quench radicals, scavenge ROS, and chelate metals without serious side effects [24]. In addition, DHLA can regenerate endogenous antioxidants, such as glutathione, vitamin E, and vitamin $\mathrm{C}$, by direct reduction of their oxidized forms $[25,26] . \alpha-\mathrm{LA}$ as an antioxidant has been used to treat diabetic neuropathy, liver-related pathologies, atherosclerosis, and aging-related diseases [27-30]. Given all these properties, we speculate that $\alpha$-LA might protect KGFR and improve KGF resistance by attenuating oxidative stress.

In this study, we investigated the potential molecular mechanism of oxidative-stressinduced KGF resistance. We also explored the optimal strategy to combine KGF and $\alpha$-LA and their application as protection from hyperoxia-induced lung injury in vitro.

\section{Materials and Methods}

Isolation and Primary Culture of Alveolar Type II Epithelial Cells (ATIICs)

The animal experiment was approved by the Committee of the Ethics of Animal Experiments of Huazhong University of Science and Technology. Healthy and adult Sprague-Dawley rats weighing 200g 


\section{Cellular Physiology and Biochemistry}

Cell Physiol Biochem 2014;33:953-966

\begin{tabular}{l|l}
\hline DOI: $10.1159 / 000358667$ & (c) 2014 S. Karger AG, Basel
\end{tabular}

Wang et al.: $\alpha$-LA Combined with KGF Protects Alveolar Epithelial Type II Cells from Hyperoxia-Induced Injury

to $300 \mathrm{~g}$ were provided by the Laboratory Animal Center of Tongji Medical College, Huazhong University of Science and Technology. Food pellets and water were administered ad libitum to the dams. Male and female rats were kept on a 12:12-h light-dark cycle and mated with 1:2 to 1:3 at night. The following morning, observed sperms in vaginal smear under light microscope was determined as fertilization, and marked as Day 1. Pregnant rats on day 19 were anesthetized intraperitoneally by $20 \%$ Urethane $(1 \mathrm{~mL} / \mathrm{Kg})$, and pups were obtained by cesarean section. Lungs of fetuses were dissected under aseptic conditions and ATIICs were isolated according to previously described methods [31,32]. Briefly, the lungs were washed in precooled sterile D-Hanks solution and cut into tiny pieces less than $0.5 \mathrm{~mm}$ in size by using a razor blade. Then, the pieces were incubated with $0.25 \%$ trypsin for $15 \mathrm{~min}$ at $37^{\circ} \mathrm{C}$, followed by sequential incubation with $0.2 \mathrm{~g} / \mathrm{L}$ Dnase and $1.0 \mathrm{mg} / \mathrm{mL}$ collagenase for $15 \mathrm{~min}$ at $37^{\circ} \mathrm{C}$. The cell suspensions were filtrated through a $100-\mathrm{mm}$ Falcon nylon cell strainer and centrifuged at $1500 \mathrm{rpm}$ for $10 \mathrm{~min}$. Next, the cell pellets were resuspended with $10 \%$ FCS-MEM and planted on plastic to allow fibroblast adherence for three successive 45 min steps. The supernatants from the last differential adherence were centrifuged, resuspended, and plated at $1 \times 10^{6} / \mathrm{mL}$ in 6 or 96 well plates at $37{ }^{\circ} \mathrm{C}$ in a $5 \% \mathrm{CO}_{2}$-containing incubator. Finally, fresh culture medium was replaced after $15 \mathrm{~h}$ to $18 \mathrm{~h}$ to further remove non-adherent cells. The $95 \%$ purity of the ATIICs was proved according to this protocol.

\section{Cell Treatment}

Cells that grew to $80 \%$ confluence were randomly divided into air and hyperoxia group. The air group was cultured at $37{ }^{\circ} \mathrm{C}$ in a $5 \% \mathrm{CO}_{2}$-containing incubator, and the hyperoxia group was placed in a sealed, sterilized, and humidified chamber filled with $95 \% \mathrm{O}_{2}$ and $5 \% \mathrm{CO}_{2}$. A digital oxygen monitor was used to measure the $\mathrm{O}_{2}$ concentration inside the chamber in real-time. To evaluate the effects of hyperoxia and KGF on cell viability, rhKGF (R\&D system, USA) was added into the culture medium at final concentrations of $0,15,25,50,75$, and $100 \mathrm{ng} / \mathrm{mL}$ before exposure to hyperoxia for $1 \mathrm{~h}$. Moreover, $0.5 \mathrm{mM} \alpha$-lipoic acid (Sigma, USA) was administered to investigate synergistic effect between KGF and $\alpha$-lipoic acid. In addition, cells were treated with following inhibitors to explore the protential mechanism: pifithrin- $\alpha(20 \mu \mathrm{M}$, p53 inhibitor, Beyotime Institute of Biotechnology, China) and trichostatin A (1 $\mu \mathrm{M}$, histone deacetylase inhibitor, Beyotime Institute of Biotechnology, China). The inhibitors were added $1 \mathrm{~h}$ before hyperoxia. In KGF and inhibitor co-treatment experiments, cells were preincubated with the inhibitors for $30 \mathrm{~min}$, and then treated with KGF before hyperoxic exposure.

\section{Measure of ROS by Flow Cytometry}

ROS Assay Kit was purchased from Beyotime Institute of Biotechnology (Wuhan, China). According to the instruction, fluorescent probe DCFH-DA $\left(2^{\prime}, 7^{\prime}\right.$-dichlorofluorescin diacetate) was diluted 1:2500 with serum-free medium. Cells after treatment were incubated with the diluent away from light at $37^{\circ} \mathrm{C}$ for $30 \mathrm{~min}$, washed by D-Hanks thrice to remove excess probe, and digested into the suspension cells with $0.25 \%$ trypsin solution. Average intracellular fluorescence intensity of DCF was detected by FACSAria flow cytometer with excitation and emission at 488 and $525 \mathrm{~nm}$, respectively. Results were analyzed by Cell Quest software.

\section{Cell Viability Assay}

Cell viability was evaluated using the tetrazolium salt 3-(4,5-dimethyl-thiazol-2-yl)-2,5-diphenyltetrazolium bromide (MTT, Sigma-Aldrich) colorimetric assay. After treatment, the cells were incubated with serum-free medium containing $0.5 \mu \mathrm{g} / \mathrm{mL}$ MTT away from light at $37^{\circ} \mathrm{C}$ for $3 \mathrm{~h}$. Then medium was replaced by $0.25 \mathrm{~mL}$ DMSO, shaking gently for $10 \mathrm{~min}$. Finally $200 \mu \mathrm{L}$ of supernatant were transferred to a 96 -well plate to measure absorbance at $520 \mathrm{~nm}$. Background values were subtracted from the sample readings.

\section{Cytotoxicity Assay}

Cytotoxicity was detected by measuring lactate dehydrogenase (LDH) quantitatively with CytoTox 96® Non-Radioactive Cytotoxicity Assay (Promega, China). Following the protocol, $50 \mathrm{uL}$ of cell supernatant was transferred to a 96-well assay plate after treatment, mixed with $50 \mu \mathrm{L}$ reconstitute substrate mix, and then incubated the plates for $30 \mathrm{~min}$ at room temperature protected from light. A total of $50 \mu \mathrm{L}$ Stop Solution was added, and absorbance at 490nm was recorded. Background values were subtracted from the sample readings. 


\section{Cellular Physiology \\ and Biochemistry}

Cell Physiol Biochem 2014;33:953-966

\begin{tabular}{l|l}
\hline DOI: $10.1159 / 000358667$ & (C) 2014 S. Karger AG, Basel
\end{tabular}

www.karger.com/cpb

Wang et al.: $\alpha$-LA Combined with KGF Protects Alveolar Epithelial Type II Cells from Hyperoxia-Induced Injury

RNA extraction and reverse transcription

Total RNA was extracted using the guanidinium isothiocynate method (TRIzol reagent, Invitrogen, USA). The cells after treatment were washed twice with D-Hanks, and $1 \mathrm{~mL}$ of TRIzol was added to each well and allowed to stand at room temperature for $5 \mathrm{~min}$. The mixture was transferred into a sterile Eppendorf tube, and $200 \mu \mathrm{L}$ of chloroform was added to the mixture. The mixture was allowed to stand at room temperature for $15 \mathrm{~min}$ after blending by hands and then centrifuged at $12,000 \mathrm{rpm}$ for $5 \mathrm{~min}$ at $4{ }^{\circ} \mathrm{C}$. The upper aqueous phase was carefully absorbed, transferred to an RNase-free Eppendorf tube, mixed with 0.5 $\mathrm{mL}$ of isopropanol, and then centrifuged at $12,000 \mathrm{rpm}$ for $10 \mathrm{~min}$ at $4{ }^{\circ} \mathrm{C}$. The supernatant was discarded, and $1 \mathrm{~mL}$ of $75 \%$ ethanol was added to the tube. The mixture was centrifuged at $8,000 \mathrm{rpm}$ for $8 \mathrm{~min}$ at $4{ }^{\circ} \mathrm{C}$. Afterwards, the supernatant was discarded, and the pellet was redissolved in DEPC-treated sterile $\mathrm{ddH}_{2} \mathrm{O}$. The purity and concentration of RNA was identified with an ultraviolet spectrophotometer. Next, RNA was reverse transcribed into cDNA by First-Strand cDNA Synthesis Kit (GeneCopoeia, China) according to the instruction.

\section{Quantitative RT-PCR analysis}

Real-time PCR primers were synthesized by Qingke Biotechnology Co. Ltd (Wuhan, China). Forward and reverse primer pairs of KGFR and $\beta$-actin were 5'-AAGCAGGAGCATCGCATCG-3' and 5'-CATCAAGGTGGTAGG TGTGGTT-3' (amplified fragment length 148bp), and 5'-CAACCACACCTACCACCTT-3' and 5'-TGAACA GAGCCAGCACTT-3' (amplified fragment length 266bp), respectively. Then, $10 \mu \mathrm{L}$ SYBR Green Real-time PCR Master Mix (TaKaRa, China), $0.4 \mu \mathrm{L}$ primer pairs, $2 \mu \mathrm{L}$ cDNA, and $7.2 \mu \mathrm{L} \mathrm{ddH_{2 }}$ O were mixed. The mixture was incubated at $95{ }^{\circ} \mathrm{C}$ for $5 \mathrm{~s}$ and at $58{ }^{\circ} \mathrm{C}$ for $20 \mathrm{~s}$, and this process was repeated for 40 cycles. Real-time PCR was performed on LightCycler device (Applied Roche Diagnostics). Melt curve analysis was used to check amplification of a single specific product. Relative expression was determined using the $\Delta \Delta \mathrm{Ct}$ (threshold cycle) method of samples $(\Delta \mathrm{Ct})$. Fold change $=2^{-\Delta \Delta C \mathrm{Ct}} ; \Delta \Delta \mathrm{Ct}=\left(\mathrm{Ct}_{\text {sample }}-\mathrm{Ct}_{\text {reference }}\right)_{\text {treat }}-\left(\mathrm{Ct}_{\text {sample }}-\mathrm{Ct}_{\text {reference }}\right)_{\text {control }}$. All experiments were performed in triplicate.

\section{Co-Immunoprecipitation (Co-IP)}

Cultured cells with pre-chilled PBS were carefully washed twice and cold RIPA lysis buffer was added. Cells were scraped off and transferred into $1.5 \mathrm{~mL}$ eppendorf tubes, and centrifuge at $14,000 \times g$ at $4{ }^{\circ} \mathrm{C}$ for $15 \mathrm{~min}$. The supernatants were immediately transferred into new tubes, and $50 \%$ protein $\mathrm{A} / \mathrm{G}$ agarose with ratio of $100 \mu \mathrm{L}$-to- $1 \mathrm{~mL}$ sample solution was added. The tubes were shaken on a horizontal shaker for 10 min at $4{ }^{\circ} \mathrm{C}$ to eliminate non-specific binding proteins. Then, the tubes were centrifuged at $14,000 \times g$ at $4{ }^{\circ} \mathrm{C}$ for $15 \mathrm{~min}$, and the supernatants were transferred into new tubes. The mixture of $400 \mu \mathrm{g}$ total protein with p53 mouse monoclonal antibody (Santa Cruz, USA) was shaked slowly at $4{ }^{\circ} \mathrm{C}$ overnight. Then, the mixture was centrifuged at $14,000 \times g$ for $5 \mathrm{~s}$ to keep the pellet and washed with pre-chilled cold PBS for thrice. The supernatants were collected and analyzed by Western blot

\section{Western Blot Analysis}

Protein expression of KGFR, phospho-p53, histone deacetylase (HDAC), acetylated H3 and H4 was analyzed by Western blot. Total proteins were extracted by $2 \times$ SDS $(0.77 \mathrm{~g}$ DTT, $4 \mathrm{~mL} 1 \mathrm{M}$ Tris-HCl pH 6.8, $5 \mathrm{~mL} \mathrm{20 \%} \mathrm{SDS,} 5 \mathrm{~mL}$ glycerin, $750 \mu \mathrm{L} \mathrm{1 \%}$ bromophenol blue in ethanol solution, and $\mathrm{ddH}_{2} \mathrm{O}$ to make a 50 $\mathrm{mL}$ solution), quantified by amido black dye-binding method, electrophoresed in $8 \%$ to $10 \%$ SDS-PAGE gel, and transferred to nitrocellulose membrane by electrophoresis. The membranes were blocked for $1 \mathrm{~h}$ in $5 \%$ skim milk or BSA and incubated overnight at $4{ }^{\circ} \mathrm{C}$ with the primary antibodies at optimal dilutions (KGFR 1:2000, Abcam, USA; phospho-p53 1:500, Abcam, USA; HDAC 1:200, Santa Cruz, USA; acetylated H3, 1:500, Millipore, USA; acetylated H4 1:1000, CST, USA). Membranes were washed in TBST (TBS/0.1\% Tween-20) to remove excess primary antibodies, incubated for $1 \mathrm{~h}$ with horseradish peroxidase-conjugated secondary antibodies (1:8000-1:10000, Abcam, USA), and then washed thrice in TBST. The protein bands were visualized using an enhanced chemiluminescence kit (Thermo-fisher, USA) and exposed to Kodak Image Station Pro System for optimal duration. Densitometry analysis of blots was performed using ImageJ software.

\section{Statistical Analysis}

Data are expressed as means \pm SD. Data were analyzed statistically using ANOVA or unpaired Student's t-test. $\mathrm{P}<0.05$ was considered statistically significant. 


\section{Cellular Physiology \\ and Biochemistry}

Cell Physiol Biochem 2014;33:953-966

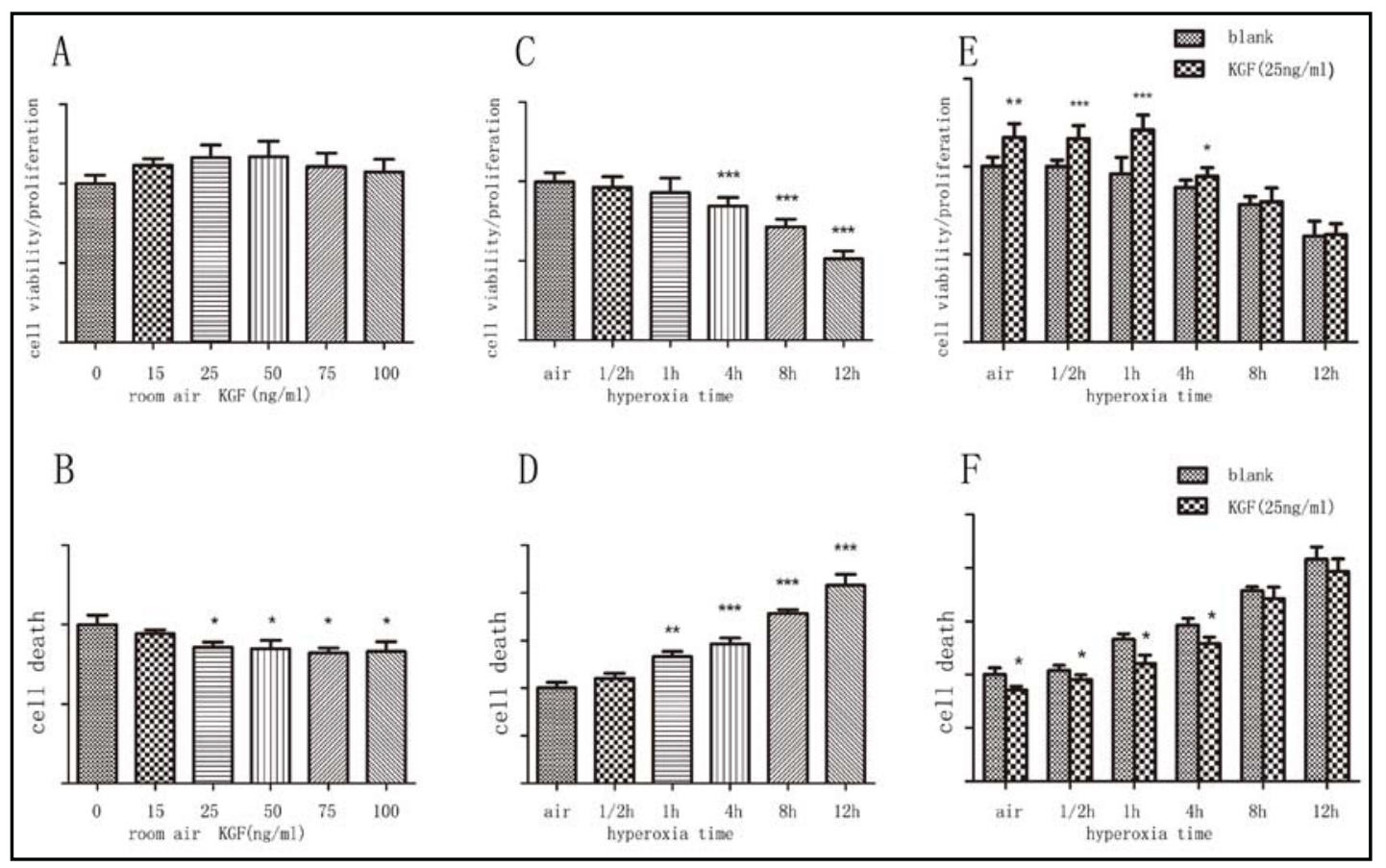

Fig. 1. Effects of KGF on ATIICs proliferation and necrosis under room air and hyperoxic condition. Cell proliferation/viability and death were detected by MTT assay and release of LDH in culture medium, respectively. ATIICs were treated first with various concentrations of KGF under room air condition, (A) proliferation increased at $15 \mathrm{ng} / \mathrm{mL}$ to $75 \mathrm{ng} / \mathrm{mL}\left({ }^{*} \mathrm{p}<0.05,{ }^{* *} \mathrm{p}<0.01\right)$, and (B) lower death count was observed at $25 \mathrm{ng} / \mathrm{mL}$ to $100 \mathrm{ng} / \mathrm{mL}$ compared with those in the blank $\left({ }^{*} \mathrm{p}<0.05\right)$. Then, cells were cultured under $95 \% \mathrm{O}_{2}$ and $5 \% \mathrm{CO}_{2}$ at $37^{\circ} \mathrm{C}$. (C) Viability decreased markedly after $4 \mathrm{~h}$ hyperoxic exposure $(* * * \mathrm{p}<0.001)$, and release of LDH in medium increased during $4 \mathrm{~h}$ to $12 \mathrm{~h}$ (Fig.1D, ${ }^{* *} \mathrm{p}<0.01,{ }^{* * *} \mathrm{p}<0.001$ ) compared to air group. Finally, cells exposed to hyperoxia were treated with $25 \mathrm{ng} / \mathrm{mL}$ of KGF. (D) and (E) Higher viability and lower LDH release were detected in the KGF group compared with those in the blank under room air and temporary exposure to oxygen. However, no significant difference was found in cell viability and death between KGF and blank groups after 8 and $12 \mathrm{~h}$ hyperoxic exposure. Data represent the mean \pm standard deviation of three independent experiments.

\section{Results}

Effects of KGF on proliferation and death of ATIICs exposed to room air and hyperoxia

Cell proliferation and mortality was assessed by 3-(4,5-dimethylthiazol-2-yl)-2,5diphenyltetr azolium bromide (MTT) and release of lactate dehydrogenase (LDH) in medium, respectively. Under room air, KGF could significantly increase ATIICs proliferation from $15 \mathrm{ng} / \mathrm{mL}$ up to $100 \mathrm{ng} / \mathrm{mL}$ in a dose-dependent manner and significantly decrease $\mathrm{LDH}$ production at concentrations from $25 \mathrm{ng} / \mathrm{mL}$ to $100 \mathrm{ng} / \mathrm{mL}\left({ }^{*} \mathrm{p}<0.05,{ }^{* *} \mathrm{p}<0.01\right.$, Figs. $1 \mathrm{~A}$ and $1 \mathrm{~B})$. However, cell viability decreased and LDH release increased significantly in a time-dependent manner when ATIICs were exposed to $95 \% \mathrm{O}_{2}$ for more than $4 \mathrm{~h}\left({ }^{* *} \mathrm{p}<0.01\right.$, $* * * p<0.001$, Figs. 1C and 1D). Furthermore, cells treated with $25 \mathrm{ng} / \mathrm{mL}$ KGF were exposed to hyperoxia for various durations. Protective effects of higher proliferation and lower necrosis were observed in the KGF group compared with those in the blank within $4 \mathrm{~h}$ after exposure $\left({ }^{*}<<0.05,{ }^{* * *} p<0.001\right.$; Figs. $1 \mathrm{E}$ and $\left.1 \mathrm{~F}\right)$. Prolonged exposure to hyperoxia for 8 and $12 \mathrm{~h}$ resulted in the loss of the protective function of KGF on ATIICs. Moreover, no significant difference in viability and mortality was found between the KGF and blank groups ( $p>0.05)$. Meanwhile, compared with the blank, administered dosages up to $100 \mathrm{ng} / \mathrm{mL}$ of KGF did not result in higher viability and decreased LDH release after $12 \mathrm{~h}$ culture of ATIICs under $95 \% \mathrm{O}_{2}$ (data not shown). These results indicated that prolonged exposure to high oxygen concentration could result in less sensitivity of ATIICs to KGF. 


\section{Cellular Physiology \\ and Biochemistry}

Cell Physiol Biochem 2014;33:953-966

\begin{tabular}{l|l}
\hline DOI: $10.1159 / 000358667$ & (C) 2014 S. Karger AG, Basel
\end{tabular}

Wang et al.: $\alpha$-LA Combined with KGF Protects Alveolar Epithelial Type II Cells from Hyperoxia-Induced Injury

Fig. 2. Significant increase in intracellular ROS level after hyperoxic exposure. Intracellular ROS levels were measured by flow cytometry after the cells were incubated with DCFH-DA. Hyperoxic exposure resulted in significant increase in intracellular ROS production in ATIICs in a time-dependent manner compared with the room air group $\left({ }^{* *} \mathrm{p}<0.01\right.$, $\left.{ }^{* * *} \mathrm{p}<0.001\right)$. Data represent the mean \pm standard deviation of three independent experiments.
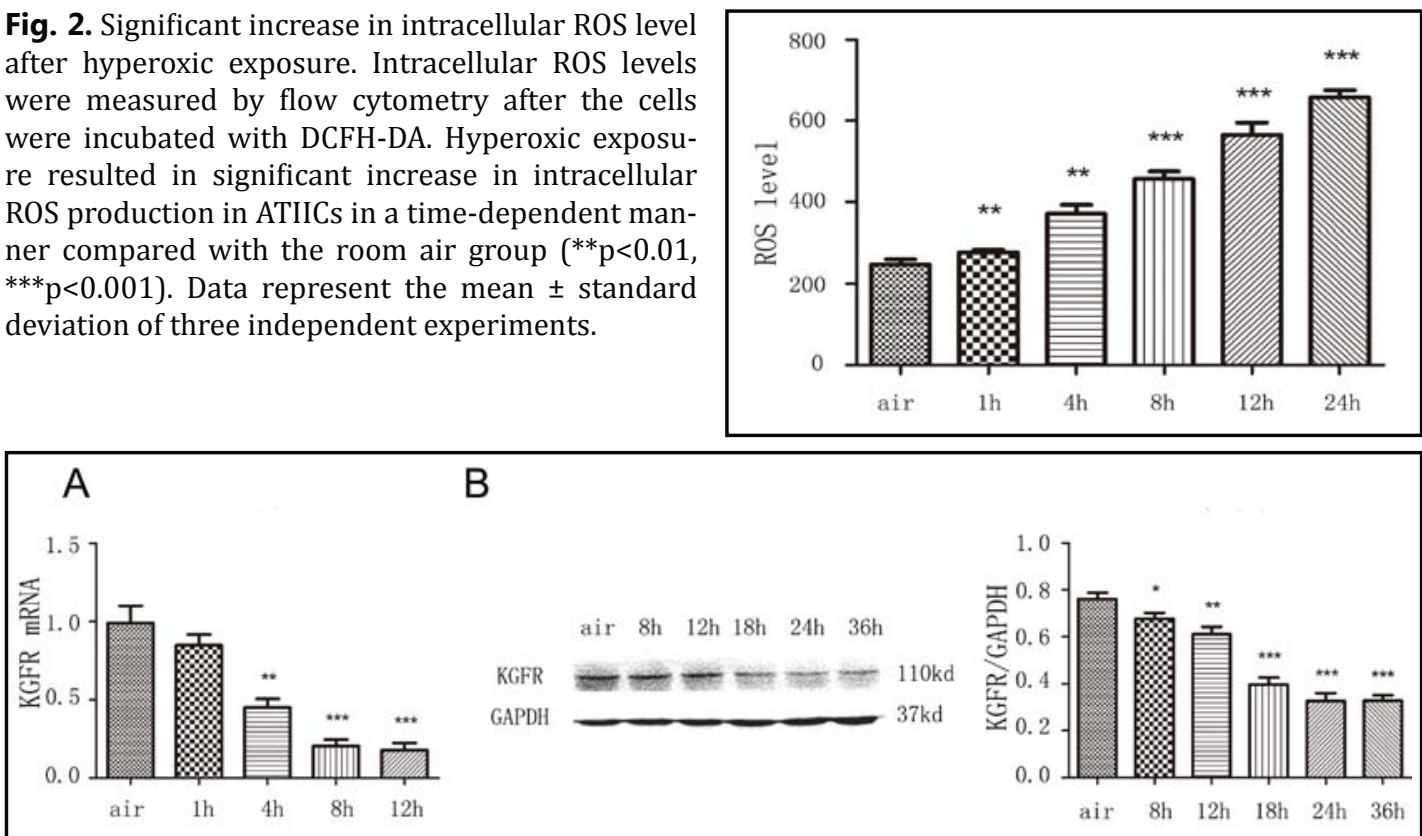

Fig. 3. Oxidative stress suppressed the KGFR gene and protein expression. KGFR mRNA and protein expression was detected by quantitative RT-PCR and Western blot, respectively. (A) Significant down-regulation of KGFR mRNA occurred at $4 \mathrm{~h}$ after hyperoxic exposure $\left({ }^{* *} \mathrm{p}<0.01\right)$. Exposure for $8 \mathrm{~h}$ to $12 \mathrm{~h}$ induced much lower expression of KGFR mRNA than that in the room air group $(* * * p<0.001)$. (B) KGFR protein expression was markedly down-regulated along with prolonged hyperoxic exposure, and lower expression of KFGR was observed at $24 \mathrm{~h}$ to $36 \mathrm{~h}$ after hyperoxic exposure $\left({ }^{*} \mathrm{p}<0.05,{ }^{* *} \mathrm{p}<0.01,{ }^{* * *} \mathrm{p}<0.001\right)$. Data represent the mean \pm standard deviation of three independent experiments.

\section{Effects of hyperoxia on intracellular ROS level of ATIICs}

Exposure to high $\mathrm{O}_{2}$ concentrations may lead to hyperoxia-induced injury through the production of ROS, which includes hydroxyl radical $(-\mathrm{OH})$, hydrogen peroxide $\left(\mathrm{H}_{2} \mathrm{O}_{2}\right)$, and superoxide radical $\left(\mathrm{O}_{2}^{-}\right)$[33]. Increased ROS generation indicates much severe oxidative stress, which subsequently results in direct damage of the cell structure and function [34]. In this study, cells were cultured under room air or hyperoxic condition, and intracellular ROS levels were measured by flow cytometry after the cells were incubated with DCFH-DA. Exposure to hyperoxia resulted in a significant increase in intracellular ROS production in ATIICs in a time-dependent manner compared with that of the room air group $(* * p<0.01$, ${ }^{* * *} \mathrm{p}<0.001$; Fig. 2). Intracellular oxidative stress induced by hyperoxia was exacerbated after prolonged exposure.

\section{Oxidative stress suppressed the KGFR gene and protein expression}

KGFR mRNA and protein expression was detected by quantitative RT-PCR and Western blot to explore the underlying mechanisms involved in reduced susceptibility of ATIICs to KGF after prolonged hyperoxic exposure. Results of real-time PCR showed that obvious reduction of KGFR mRNA occurred after $4 \mathrm{~h}$ exposure to hyperoxia. Moreover, exposure for $8 \mathrm{~h}$ to $12 \mathrm{~h}$ induced much lower KGFR mRNA expression than that of the room air group $\left({ }^{* * *} \mathrm{p}<0.001\right.$; Fig. $\left.3 \mathrm{~A}\right)$. KGFR protein expression in the ATIICs was decreased remarkably with prolonged exposure, and lower KFGR expression was observed from $24 \mathrm{~h}$ to $36 \mathrm{~h}$ under hyperoxic condition (Fig. 3B, ${ }^{*} \mathrm{p}<0.05,{ }^{* *} \mathrm{p}<0.01,{ }^{* * *} \mathrm{p}<0.001$ ).

Phosphorylation of p53 at Ser 392 and subsequent recruitment of HDAC was crucial to oxidative stress-induced KGFR down-regulation

Western blot analysis was used to further investigate the signaling mechanism that caused the down-regulation of KGFR expression after hyperoxic injury. First, our results 


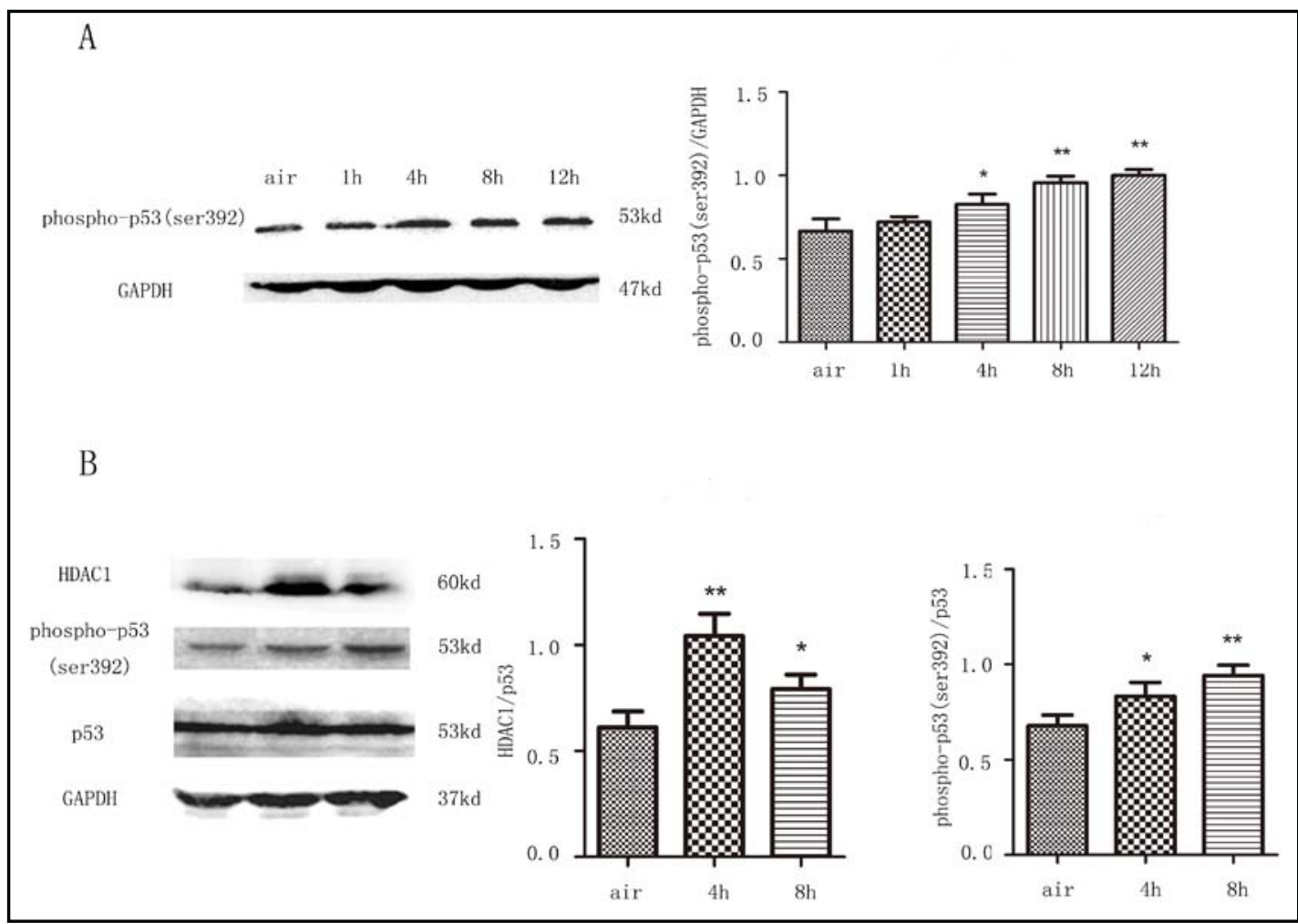

Fig. 4. Oxidative stress induces p53 phosphorylation at Ser 392 and subsequent recruitment of HDAC. Western blot was used to detect protein expression, and Co-IP was applied to investigate the association of p53 with phospho-p53 and HDAC1. (A) Expression of phospho-p53 (ser 392) in the hyperoxic group was significantly higher than that in room air group at 4,8 , and $12 \mathrm{~h}$ after hyperoxic exposure $\left({ }^{*} \mathrm{p}<0.05,{ }^{* *} \mathrm{p}<0.01\right)$. (B) HDAC-1 were markedly upregulated along with higher expression of phospho-p53 (ser392) after 4 and $8 \mathrm{~h}$ hyperoxic exposure $\left({ }^{*} \mathrm{p}<0.05,{ }^{* *} \mathrm{p}<0.01\right)$, although total $\mathrm{p} 53$ levels remained unchanged. Data represent the mean \pm standard deviation of three independent experiments.

showed that phospho-p53 (ser 392) expression of ATIICs in the hyperoxic group was significantly higher than that of the room air group at 4,8 , and $12 \mathrm{~h}$ after hyperoxic exposure (Fig. 4A, ${ }^{*}$ p $<0.05,{ }^{* *}$ p $<0.01$ ). Second, Co-IP was used to identify the association of p53 with HDAC-1. HDAC-1 was markedly upregulated after 4 and $8 \mathrm{~h}$ hyperoxic exposure and reached a plateau level at $4 \mathrm{~h}$ exposure compared with that of the room air condition group, and the total p53 levels remained unchanged (Fig. 4B, ${ }^{*}$ p $<0.05,{ }^{* *}$ p $<0.01$ ). Furthermore, pifithrin- $\alpha$ was used as p53 inhibitor to confirm the interaction of p53 with HDAC and KGFR. ATIICs were incubated with $20 \mu \mathrm{M}$ of pifithrin- $\alpha$ under $95 \% \mathrm{O}_{2}$ for $4 \mathrm{~h}$. Results from Co-IP suggested that HDAC was suppressed along with inhibition of p53 compared with that in the control (Figs. 4C and 4D). At the same time, repressive effect of hyperoxia on KGFR was ameliorated by pifithrin- $\alpha$ and down-regulation of KGFR expression attenuated in pifithrin- $\alpha$ group compared with that in the control after $12 \mathrm{~h}$ hyperoxic exposure (Fig. 4E). Therefore, p53 activation has a crucial part in hyperoxia-induced KGFR down-regulation.

\section{HDAC promoted H4 deacetylation leading to transcriptional inhibition under hyperoxic condition}

Histone acetylation promotes chromatin expansion in favor of genetic transcription. Long tails of $\mathrm{H} 3$ and $\mathrm{H} 4$ histones, protruding from the nucleosome, can be covalently modified in acetylation. HDAC removes acetyl groups on histone tails and increases condensation of DNA binding to prevent transcription. The acetyl-Histone $\mathrm{H} 3$ and $\mathrm{H} 4$ expression after hyperoxic exposure was analyzed by Western blot. Results indicated that, compared with the group under room air condition, acetylation level of $\mathrm{H} 4$ decreased significantly after 4 and 


\section{Cellular Physiology \\ and Biochemistry}

Cell Physiol Biochem 2014;33:953-966

DOI: 10.1159/000358667

Publisned online: VIarch 31, 2014

(C) 2014 S. Karger AG, Basel

Wang et al.: $\alpha$-LA Combined with KGF Protects Alveolar Epithelial Type II Cells from Hyperoxia-Induced Injury
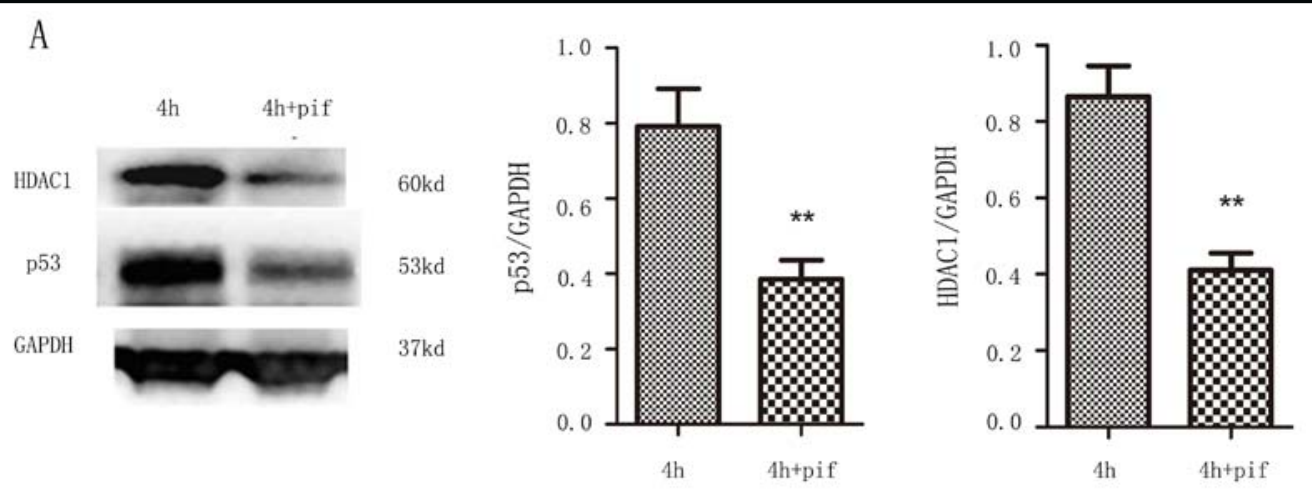

B

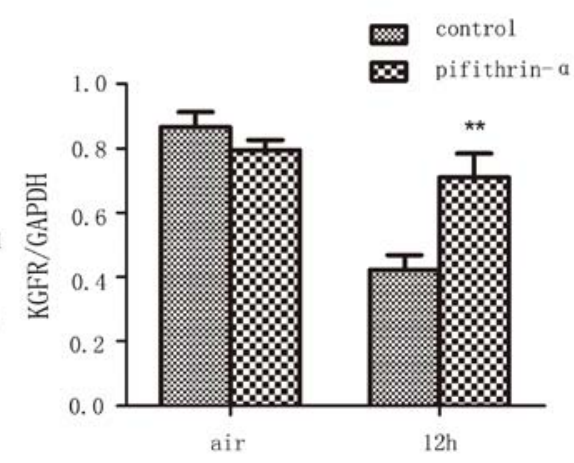

Fig. 5. Pifithrin- $\alpha$ (pif) protected KGFR by inhibiting p53 and reducing recruitment of HDAC1. ATIICs were treated with $20 \mu \mathrm{M}$ of pifithrin- $\alpha$. (A) Cells were cultured under $95 \% \mathrm{O}_{2}$ for $4 \mathrm{~h}$ after treatment, p53 expression was repressed than that of the control $(* * p<0.01)$, meanwhile HDAC1 expression was down-regulated compared with the control following inhibition of $553\left({ }^{* *} \mathrm{p}<0.01\right)$. (B) When ATIICs were cultured for $12 \mathrm{~h}$ under either room air or hyperoxic condition, down-regulated KGFR expression induced by oxidative stress was attenuated in the pifithrin- $\alpha$ group than that in the control $(* * p<0.01)$. Data represent the mean \pm standard deviation of three independent experiments.

$8 \mathrm{~h}$ exposure to hyperoxia in a time-dependent manner (Fig. $6 \mathrm{~A},{ }^{* *} \mathrm{p}<0.01,{ }^{* * *} \mathrm{p}<0.001$ ), and acetyl-H3 slightly decreased after $4 \mathrm{~h}$ exposure to hyperoxia, but no statistical difference was found (data was not shown). ATIICs were cultured in the medium with $1 \mu \mathrm{M}$ of Trichostatin A (HDAC-specific inhibitor, TSA) under $12 \mathrm{~h}$ hyperoxia. Down-regulation of KGFR expression in $12 \mathrm{~h}$ hyperoxic group was reversed markedly by TSA compared with that in the control (Fig. 6B, ${ }^{* *} \mathrm{p}<0.01$ ).

\section{Protective effect of $\alpha$-LA on KGFR by scavenging ROS and suppressing p53 activity}

$\alpha$-LA can scavenge various ROS, and $\alpha$-LA is considered as a potent antioxidant applied as a therapy of oxidative stress-associated diseases $[27,35,36]$. ATIICs were treated with $0.5 \mathrm{mM} \alpha$-LA under $95 \% \mathrm{O}_{2}$, and intracellular ROS was measured by flow cytometry. The level of intracellular ROS in $\alpha$-LA group was significantly lower than that of the hyperoxic group, and the difference became more remarkable with prolonged exposure (Fig. $7,{ }^{*} p<0.05$, $\left.{ }^{* *} \mathrm{p}<0.01,{ }^{* * *} \mathrm{p}<0.001\right)$.

The expression of phospho-p53 (ser 392) and KGFR in $\alpha$-LA group was detected by Western blot. The phospho-p53 (ser 392) expression was reduced significantly in $\alpha$-LA group than that in the control after 4 and $8 \mathrm{~h}$ hyperoxic exposure (Fig. 8A). The KGFR expression of ATIICs in the $\alpha$-LA group were 2.47- and 1.58-fold higher than those in the control under hyperoxic condition for 12 and 24 h, respectively (Fig. $8 B,{ }^{*} p<0.05,{ }^{* *} \mathrm{p}<0.01$ ). $\alpha$-LA may contribute to the protection of KGFR from oxidative stress injury by scavenging ROS and suppressing the molecular pathway of P53-HDAC-H4. 


\section{Cellular Physiology \\ and Biochemistry}

Cell Physiol Biochem 2014;33:953-966

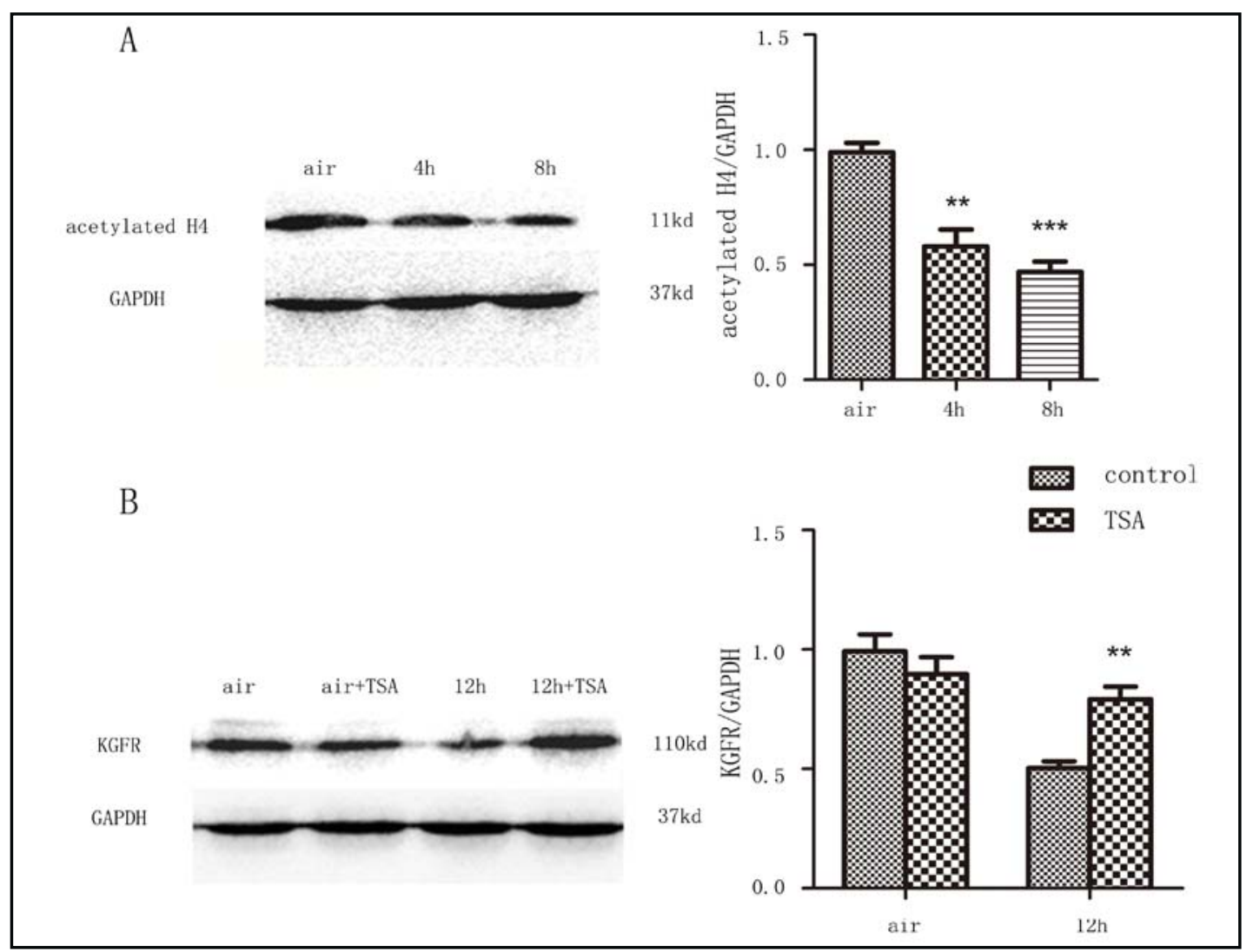

Fig. 6. HDAC promoted deacetylation of $\mathrm{H} 4$ under hyperoxic condition. (A) Compared with that under room air condition, acetylation level of $\mathrm{H} 4$ decreased significantly after 4 and $8 \mathrm{~h}$ hyperoxic exposure in a timedependent manner $\left({ }^{* *} \mathrm{p}<0.01,{ }^{* * *} \mathrm{p}<0.001\right)$. Data represent the mean \pm standard deviation of three independent experiments. (B) TSA (HDAC specific inhibitor) could suppress the down-regulation of KGFR level after $12 \mathrm{~h}$ hyperoxic exposure compared with that in the control group $\left({ }^{* *} \mathrm{p}<0.01\right)$.

Synergetic protective effects of $\alpha$-LA and KGF on the proliferation and survival of ATIICs under prolonged exposure to hyperoxia

To further explore whether ATIICs could regain the sensitivity to KGF co-cultured with $\alpha$-LA under hyperoxic condition, ATIICs viability and necrosis and quantity of LDH released were detected by MTT assay. Markedly higher viability and lower necrosis of ATIICs were detected both in KGF and $\alpha$-LA-KGF groups under room air and after $4 \mathrm{~h}$ hyperoxic exposure, compared with that in the blank (Fig. $9 ;{ }^{*} \mathrm{p}<0.05,{ }^{* *} \mathrm{p}<0.01$ ). After prolonged hyperoxic exposure for 8 and $12 \mathrm{~h}$, significant protective effect was observed only in the $\alpha$-LA-KGF group compared with the other groups $\left({ }^{* *} p<0.01,{ }^{* * *} p<0.001 ;{ }^{\mathbf{\Delta}} p<0.05,{ }^{\mathbf{\Delta}} p<0.01,{ }^{\mathbf{\Delta} \Delta} \mathrm{\Delta}<0.001\right)$. Furthermore, no significant difference was found between the blank and KGF groups ( $p>0.05$ ). These data indicated that KGF and $\alpha$-LA acted on synergetic protection of ATIICs from hyperoxia-induced injury.

\section{Discussion}

Oxidative stress mediated by excessive ROS generation has an important function in hyperoxia-induced lung injury in vivo [37]. In this study, we demonstrated that intracellular ROS production of ATIICs was increased greatly under hyperoxic condition in a timedependent manner, resulting in decreased cell viability and elevated release of LDH. Addition of KGF to ATIICs contributed to increased cell proliferation and reduced cell necrosis under room air or temporary hyperoxic exposure. The protective effect of KGF diminished and 


\section{Cellular Physiology \\ and Biochemistry}

Cell Physiol Biochem 2014;33:953-966

DOI: 10.1159/000358667

Publisned onlIne: IVIarch 31, 2014

(C) 2014 S. Karger AG, Basel

Wang et al.: $\alpha$-LA Combined with KGF Protects Alveolar Epithelial Type II Cells from Hyperoxia-Induced Injury

Fig. 7. $\alpha$-LA could effectively scavenge intracellular ROS induced by hyperoxic exposure. ATIICs exposed to $95 \%$ oxygen were treated with $0.5 \mathrm{mM}$ of $\alpha$-LA and intracellular ROS was measured by flow cytometry. Level of intracellular ROS in the $\alpha$-LA group was significantly lower than that in the hyperoxic group at any time $\left({ }^{*} \mathrm{p}<0.05,{ }^{* *} \mathrm{p}<0.01,{ }^{* * *} \mathrm{p}<0.001\right)$. Data represent the mean \pm standard deviation of three independent experiments.
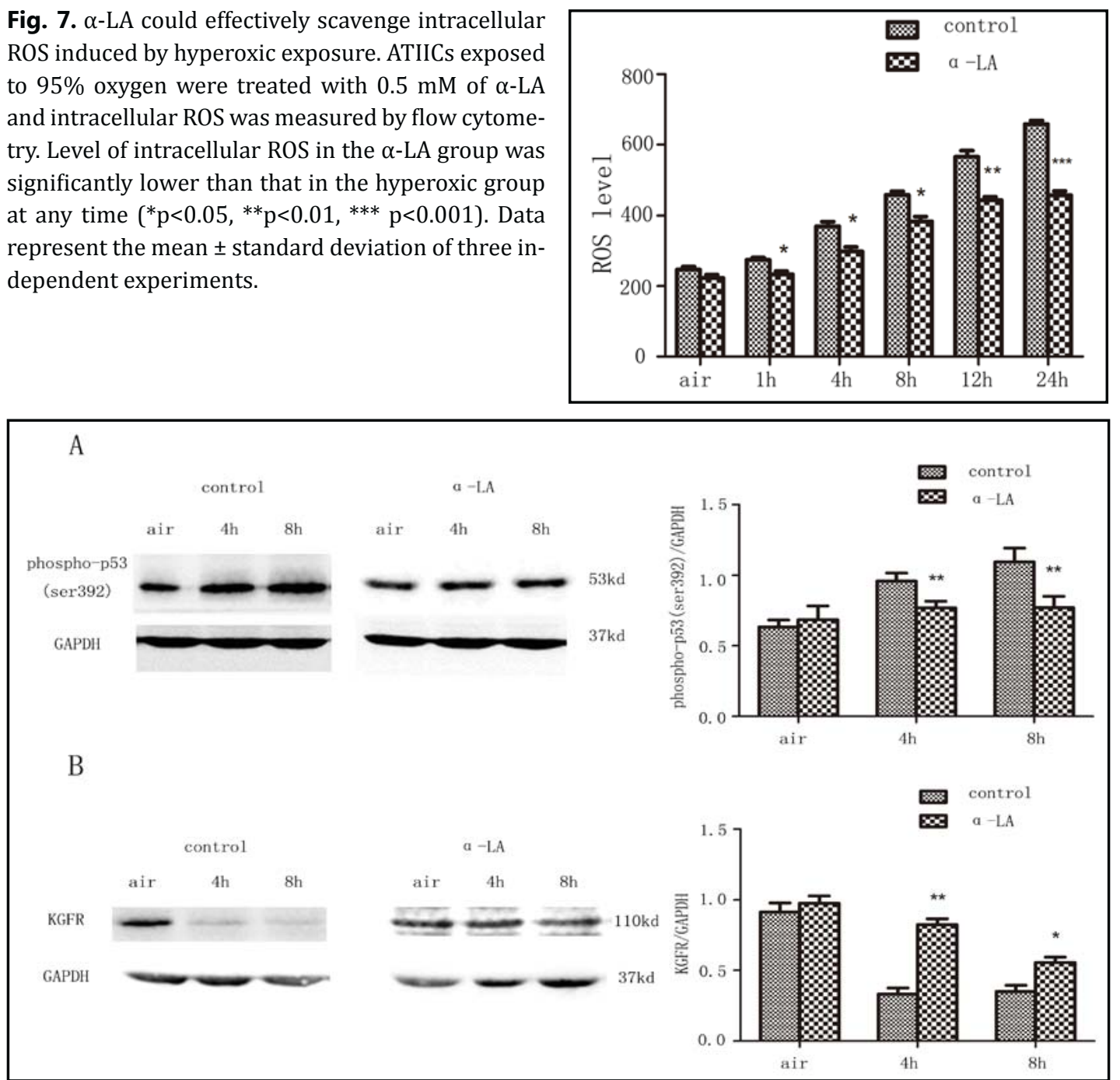

Fig. 8. $\alpha$-LA protected KGFR from oxidative stress by suppressing the activity of p53. (A) phospho-p53 (ser 392) expression was reduced significantly in the $\alpha$-LA group than that in the control after 4 and $8 \mathrm{~h}$ hyperoxic exposure $\left({ }^{*} \mathrm{p}<0.05\right)$. (B) KGFR expression in the ATIICs in the $\alpha$-LA group were 2.47 - and 1.58-fold higher, respectively, under hyperoxic condition for 12 and $24 \mathrm{~h}$ than that in the control, respectively $\left({ }^{*} \mathrm{p}<0.05\right.$, $* * \mathrm{p}<0.01$ ). Data represent the mean \pm standard deviation of three independent experiments.

sensitivity of ATIICs to KGF decreased with prolonged hyperoxic exposure, resulting in KGF resistance.

The mechanism behind KGF resistance was unclear. KGF induces cell protection through the activation of Akt pathways that prevented the Fas-induced apoptosis prior to caspase activation in A549 cell [38]. We demonstrated in our previous study that oxidative stress triggers the activation of apoptosis stimulating kinase 1 (ASK1) and p38MARK in sequence, thus inhibiting the Akt survival pathway. In addition, JNK1/2 signal pathway was activated, resulting in caspase-3-triggered apoptosis. However, this process occurred soon and was transient, which was inconsistent with the time dependence of KGF resistance. KGFR was further explored because of the relationship between ligand and receptor. We validated that transcription of KGFR mRNA began to be repressed after $4 \mathrm{~h}$ hyperoxic exposure. At the same time, KGFR protein expression decreased significantly. This behavior is consistent with ATIICs being less sensitive to KGF. Similarly, Marchese et al. demonstrated that KGFR gene and protein expression could be modulated by proinflammatory cytokines and oxidative stress [39-41], and excessive oxidative stress induced by UVB could result in the internalization of 


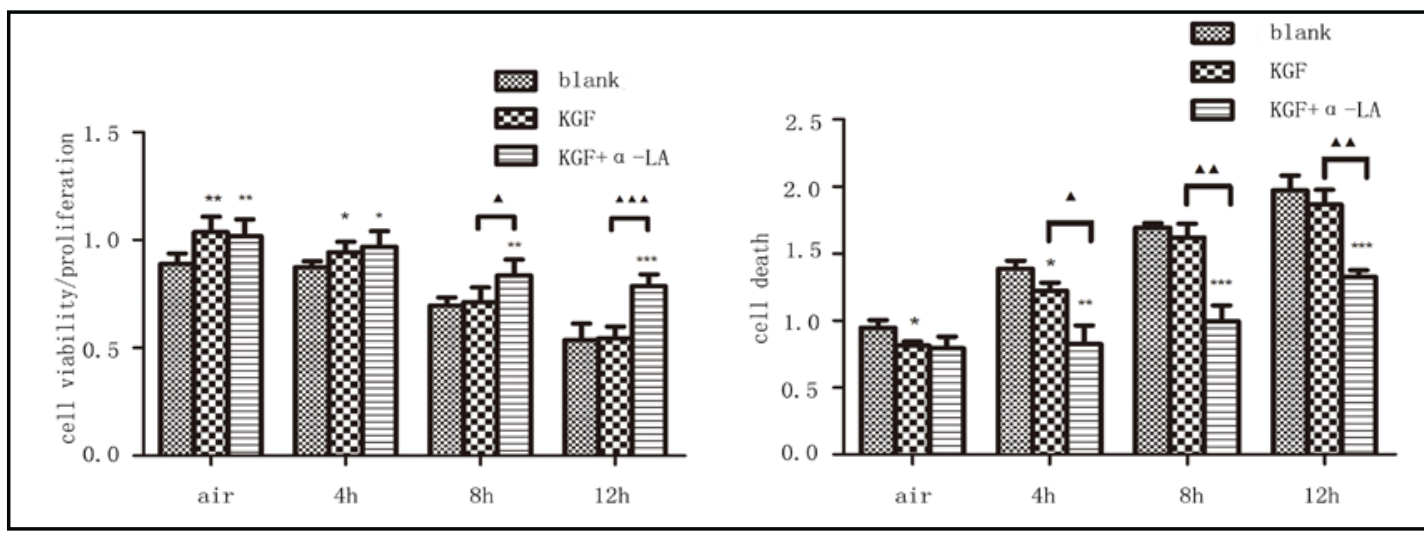

Fig. 9. Synergetic protective effects of $\alpha$-LA and KGF on the proliferation and survival of ATIICs after prolonged hyperoxic exposure. Under room air and after $4 \mathrm{~h}$ hyperoxic exposure, markedly higher viability and lower necrosis of ATIICs were detected in the KGF and $\alpha$-LA-KGF groups compared with those in the blank $\left({ }^{*} p<0.05,{ }^{* *} p<0.01\right)$. By contrast, after prolonged hyperoxic exposure for 8 and $12 \mathrm{~h}$, significant protective effect was observed only in the $\alpha$-LA-KGF group compared with those of the other groups $\left({ }^{* *} \mathrm{p}<0.01\right.$, $\left.{ }^{* * *} \mathrm{p}<0.001 ;{ }^{\Delta} \mathrm{p}<0.05,{ }^{\Delta \Delta} \mathrm{p}<0.01,{ }^{\Delta \Delta} \mathrm{\Delta} p<0.001\right)$, and no significant difference was found between the blank and the KGF group ( $\mathrm{p}>0.05)$.

KGFR after temporary UVB exposure [40]. Down-regulation was observed $6 \mathrm{~h}$ to $24 \mathrm{~h}$ after UVB exposure $[41,42]$. Therefore, down-regulation of KGFR expression induced by oxidative stress may contribute to KGF resistance.

We have investigated the potential molecular mechanisms involved in KGFR downregulation. ROS at physiologically low level has an important function in cell signaling and homeostasis as a natural by-product of the normal metabolism of oxygen [43, 44]. However, excessive ROS overwhelming antioxidant defenses may augment damage to proteins, lipids, and DNA, leading to cell dysfunction $[45,46]$. In addition, hyperoxia has been shown to directly induce DNA damage detectable by terminal transferase dUTP end-labeling in vitro [47]. Tumor suppressor p53 has an important role in apoptosis, genomic stability, and response to DNA damage induced by oxidative stress [48]. Existing studies have indicated that hyperoxia increased p53 in terminal bronchioles and ATIICs of rats and mice, resulting in the activation of downstream specific proteins $[47,49,50]$. Moreover, p53 could be activated as a transcription regulator when various stresses induce phosphorylation at certain sites located in N-terminal transcriptional activation domain. Phosphorylation of p53 at Ser392 (phospho-p53 ser ${ }^{392}$ ) was confirmed to stabilize tetramer formation of itself and provide a switch that regulates the transcriptional response to DNA damage [51]. Our study identified that the expression of phospho-p53 ser ${ }^{392}$ increased significantly at $4 \mathrm{~h}$ to $12 \mathrm{~h}$ after hyperoxic exposure, and down-regulation of KGFR expression resulting from oxidative-stress could be repressed by pifithrin- $\alpha$ (p53 inhibitor). Therefore, we speculate that p53 activation may contribute to the KGFR resistance of ATIICs under prolonged hyperoxic exposure. Next, increased association of p53 with HDAC1 was observed at 4 and $8 \mathrm{~h}$ after hyperoxic exposure. Furthermore, pifithrin- $\alpha$ as p53 inhibitor could reduce the association of p53 with HDAC1 under hyperoxic condition, confirming the recruitment of HDAC1 through p53. HDAC1 could catalyze the hydrolysis of acetyl groups on lysine residues of histones causing the condensation and coiling of chromosomal DNA around histones, thus, preventing transcription of specific genes [52]. Our data demonstrated that the acetylation level of histone $\mathrm{H} 4$ was decreased at 4 and $8 \mathrm{~h}$ after hyperoxic exposure, whereas no obvious change of acetylated histone $\mathrm{H} 3$ was detected. In addition, TSA (HDAC specific inhibitor) could suppress the down-regulation of KGFR level after $12 \mathrm{~h}$ hyperoxic exposure. Hence, we conclude that phosphorylated p53 (ser392) facilitated the down-regulation of KGFR caused by oxidative-stress. Phosphorylated p53 (ser392) subsequently recruited chromatinmodifying protein HDAC1 resulting in transcriptional repression of KGFR. 


\section{Cellular Physiology and Biochemistry}

Cell Physiol Biochem 2014;33:953-966

\begin{tabular}{l|l}
\hline DOI: $10.1159 / 000358667$ & (c) 2014 S. Karger AG, Basel
\end{tabular}

Published onlIne: VIarch 31, $2014 \quad$ www.karger.com/cpb

Wang et al.: $\alpha$-LA Combined with KGF Protects Alveolar Epithelial Type II Cells from Hyperoxia-Induced Injury

$\alpha$ - LA, also known as thioctic acid, is a naturally occurring dithiol compound and was first isolated from bovine liver in 1951 [23]. LA exists in forms of enantiomer, R-LA, and S-LA. However, only the R-LA is synthesized endogenously, serving as cofactor of mitochondrial enzyme complexes in energy metabolism [53]. Both LA and DHLA have biological activities in vivo as potential antioxidants, which are responsible for the chelation of metal ions, regeneration of exogenous and endogenous antioxidants, and repair of oxidized proteins [54, 55]. In the present study, addition of LA contributed to the effective induction of scavenge intracellular ROS by hyperoxia. This reaction subsequently protected KGFR from oxidativestress injury through inhibition of the activation of phosphorylated p53 (ser392) under hyperoxic condition. Moreover, increased proliferation and reduced necrosis were observed when ATIICs were treated with KGF and LA synergistically under prolonged hyperoxic exposure for $8 \mathrm{~h}$ and $12 \mathrm{~h}$.

In summary, the current study demonstrated that KGF promoted proliferation and inhibited apoptosis of rat fetal ATIICs in room air or under temporary hyperoxic exposure in vitro, whereas prolonged hyperoxic exposure may decrease the sensitivity of ATIICs to KGF and limit its protective effects on lung injury. Moreover, KGF resistance was mainly attributed to oxidative-stress-induced repression of KFGR in transcription and protein level through p53 phosphorylation and enhanced association of p53 with HDAC1. In addition, LA could attenuate KGF resistance by protecting KGFR under hyperoxic condition. Therefore, the synergy of KGF and LA performed optimal protective effect on ATIICs from hyperoxiainduced injury. These findings provided new insights into the prevention and therapy for hyperoxia-induced lung injury.

\section{Conflict of Interest}

The authors have no conflict of interest to declare.

\section{Acknowledgements}

This work was supported by the National Natural Science Foundation of China (No. 81170001, No. 81000261).

\section{References}

1 Ray PD, Huang BW, Tsuji Y: Reactive oxygen species (ROS) homeostasis and redox regulation in cellular signaling. Cell Signal 2012;24:981-990.

2 Circu ML, Aw TY: Reactive oxygen species, cellular redox systems, and apoptosis. Free Radic Biol Med 2010;48:749-762.

-3 Crapo JD, Peters-Golden M, Marsh-Salin J, Shelburne JS: Pathologic changes in the lungs of oxygen-adapted rats: a morphometric analysis. Lab Invest 1978;39:640-653.

-4 Crapo JD, Barry BE, Foscue HA, Shelburne J: Structural and biochemical changes in rat lungs occurring during exposures to lethal and adaptive doses of oxygen. Am Rev Respir Dis 1980;122:123-143.

-5 Rubin JS, Osada H, Finch PW, Taylor WG, Rudikoff S, Aaronson SA: Purification and characterization of a newly identified growth factor specific for epithelial cells. Proc Natl Acad Sci U S A 1989;86:802-806.

6 Tsuboi R, Sato C, Kurita Y, Ron D, Rubin JS, Ogawa H: Keratinocyte growth factor (FGF-7) stimulates migration and plasminogen activator activity of normal human keratinocytes. J Invest Dermatol 1993;101:49-53.

-7 Marchese C, Rubin J, Ron D, Faggioni A, Torrisi MR, Messina A, Frati L, Aaronson SA: Human keratinocyte growth factor activity on proliferation and differentiation of human keratinocytes: differentiation response distinguishes KGF from EGF family. J Cell Physiol 1990;144:326-332.

8 Werner S, Peters KG, Longaker MT, Fuller-Pace F, Banda MJ, Williams LT: Large induction of keratinocyte growth factor expression in the dermis during wound healing. Proc Natl Acad Sci U S A 1992;89:68966900. 


\section{Cellular Physiology and Biochemistry}

Cell Physiol Biochem 2014;33:953-966

\begin{tabular}{l|l}
\hline DOI: $10.1159 / 000358667$ & (C) 2014 S. Karger AG, Basel
\end{tabular}

Wang et al.: $\alpha$-LA Combined with KGF Protects Alveolar Epithelial Type II Cells from Hyperoxia-Induced Injury

9 Ichimura T, Finch PW, Zhang G, Kan M, Stevens JL: Induction of FGF-7 after kidney damage: a possible paracrine mechanism for tubule repair. Am J Physiol 1996;271:F967-976.

10 Baskin LS, Sutherland RS, Thomson AA, Nguyen HT, Morgan DM, Hayward SW, Hom YK, DiSandro M, Cunha GR: Growth factors in bladder wound healing. J Urol 1997;157:2388-2395.

-11 Cai Y, Wang W, Liang H, Sun L, Teitelbaum DH, Yang H: Keratinocyte growth factor pretreatment prevents radiation-induced intestinal damage in a mouse model. Scand J Gastroenterol 2013;48:419-426.

12 Sun DP, Yeh CH, So E, Wang LY, Wei TS, Chang MS, Hsing CH: Interleukin (IL)-19 promoted skin wound healing by increasing fibroblast keratinocyte growth factor expression. Cytokine 2013;62:360-368.

-13 Lu Y, Pan ZZ, Devaux Y, Ray P: p21-activated protein kinase 4 (PAK4) interacts with the keratinocyte growth factor receptor and participates in keratinocyte growth factor-mediated inhibition of oxidant-induced cell death. J Biol Chem 2003;278:10374-10380.

14 Waters CM, Savla U, Panos RJ: KGF prevents hydrogen peroxide-induced increases in airway epithelial cell permeability. Am J Physiol 1997;272:L681-689.

15 Prince LS, Karp PH, Moninger TO, Welsh MJ: KGF alters gene expression in human airway epithelia: potential regulation of the inflammatory response. Physiol Genomics 2001;6:81-89.

16 Chelly N, Henrion A, Pinteur C, Chailley-Heu B, Bourbon JR: Role of keratinocyte growth factor in the control of surfactant synthesis by fetal lung mesenchyme. Endocrinology 2001;142:1814-1819.

17 Chelly N, Mouhieddine-Gueddiche OB, Barlier-Mur AM, Chailley-Heu B, Bourbon JR: Keratinocyte growth factor enhances maturation of fetal rat lung type II cells. Am J Respir Cell Mol Biol 1999;20:423-432.

$>18$ Mouhieddine-Gueddiche OB, Pinteur C, Chailley-Heu B, Barlier-Mur AM, Clement A, Bourbon JR: Dexamethasone potentiates keratinocyte growth factor-stimulated SP-A and SP-B gene expression in alveolar epithelial cells. Pediatr Res 2003;53:231-239.

19 Chandel NS, Budinger GR, Mutlu GM, Varga J, Synenki L, Donnelly HK, Zirk A, Eisenbart J, Jovanovic B, Jain M: Keratinocyte growth factor expression is suppressed in early acute lung injury/acute respiratory distress syndrome by smad and c-Abl pathways. Crit Care Med 2009;37:1678-1684.

20 Barazzone C, Donati YR, Rochat AF, Vesin C, Kan CD, Pache JC, Piguet PF: Keratinocyte growth factor protects alveolar epithelium and endothelium from oxygen-induced injury in mice. Am J Pathol 1999;154:1479-1487.

21 Panos RJ, Bak PM, Simonet WS, Rubin JS, Smith LJ: Intratracheal instillation of keratinocyte growth factor decreases hyperoxia-induced mortality in rats. J Clin Invest 1995;96:2026-2033.

-22 Franco-Montoya ML, Bourbon JR, Durrmeyer X, Lorotte S, Jarreau PH, Delacourt C: Pulmonary effects of keratinocyte growth factor in newborn rats exposed to hyperoxia. Am J Physiol Lung Cell Mol Physiol 2009;297:L965-976.

23 Reed LJ: A trail of research from lipoic acid to alpha-keto acid dehydrogenase complexes. J Biol Chem 2001;276:38329-38336.

-24 Goraca A, Huk-Kolega H, Piechota A, Kleniewska P, Ciejka E, Skibska B: Lipoic acid - biological activity and therapeutic potential. Pharmacol Rep 2011;63:849-858.

-25 Bast A, Haenen GR: Lipoic acid: a multifunctional antioxidant. Biofactors 2003;17:207-213.

-26 Biewenga GP, Haenen GR, Bast A: The pharmacology of the antioxidant lipoic acid. Gen Pharmacol 1997;29:315-331.

-27 Ziegler D, Ametov A, Barinov A, Dyck PJ, Gurieva I, Low PA, Munzel U, Yakhno N, Raz I, Novosadova M: Oral treatment with alpha-lipoic acid improves symptomatic diabetic polyneuropathy: the SYDNEY 2 trial. Diabetes Care 2006;29:2365-2370.

-28 Foo NP, Lin SH, Lee YH, Wu MJ, Wang YJ: alpha-Lipoic acid inhibits liver fibrosis through the attenuation of ROS-triggered signaling in hepatic stellate cells activated by PDGF and TGF-beta. Toxicology 2011;282:3946.

-29 Ying Z, Kherada N, Farrar B, Kampfrath T, Chung Y, Simonetti O, Deiuliis J, Desikan R, Khan B, Villamena F: Lipoic acid effects on established atherosclerosis. Life Sci 2010;86:95-102.

-30 Suh JH, Shenvi SV, Dixon BM, Liu H, Jaiswal AK, Liu RM, Hagen TM: Decline in transcriptional activity of Nrf2 causes age-related loss of glutathione synthesis, which is reversible with lipoic acid. Proc Natl Acad Sci U S A 2004;101:3381-3386.

-31 Post M, Smith BT: Histochemical and immunocytochemical identification of alveolar type II epithelial cells isolated from fetal rat lung. Am Rev Respir Dis 1988;137:525-530.

-32 Chen Y, Chang L, Li W, Rong Z, Liu W, Shan R, Pan R: Thioredoxin protects fetal type II epithelial cells from hyperoxia-induced injury. Pediatr Pulmonol 2010;45:1192-1200. 


\section{Cellular Physiology and Biochemistry}

Cell Physiol Biochem 2014;33:953-966

\begin{tabular}{l|l}
\hline DOI: $10.1159 / 000358667$ & (C) 2014 S. Karger AG, Basel
\end{tabular}

Wang et al.: $\alpha$-LA Combined with KGF Protects Alveolar Epithelial Type II Cells from Hyperoxia-Induced Injury

-33 Berkelhamer SK, Kim GA, Radder JE, Wedgwood S, Czech L, Steinhorn RH, Schumacker PT: Developmental differences in hyperoxia-induced oxidative stress and cellular responses in the murine lung. Free Radic Biol Med 2013;61:51-60.

-34 Auten RL, Whorton MH, Nicholas Mason S: Blocking neutrophil influx reduces DNA damage in hyperoxiaexposed newborn rat lung. Am J Respir Cell Mol Biol 2002;26:391-397.

-35 Haenen GR, Bast A: Scavenging of hypochlorous acid by lipoic acid. Biochem Pharmacol 1991;42:22442246.

- 36 Scott BC, Aruoma OI, Evans PJ, O'Neill C, Van der Vliet A, Cross CE, Tritschler H, Halliwell B: Lipoic and dihydrolipoic acids as antioxidants. A critical evaluation. Free Radic Res 1994;20:119-133.

- 37 Pace PW, Yao LJ, Wilson JX, Possmayer F, Veldhuizen RA, Lewis JF: The effects of hyperoxia exposure on lung function and pulmonary surfactant in a rat model of acute lung injury. Exp Lung Res 2009;35:380-398.

- 38 Bao S, Wang Y, Sweeney P, Chaudhuri A, Doseff AI, Marsh CB, Knoell DL: Keratinocyte growth factor induces Akt kinase activity and inhibits Fas-mediated apoptosis in A549 lung epithelial cells. Am J Physiol Lung Cell Mol Physiol 2005;288:L36-42.

-39 D'Amici S, Ceccarelli S, Vescarelli E, Romano F, Frati L, Marchese C, Angeloni A: TNFalpha modulates Fibroblast Growth Factor Receptor 2 gene expression through the pRB/E2F1 pathway: identification of a non-canonical E2F binding motif. PLoS One 2013;8:e61491.

40 Marchese C, Maresca V, Cardinali G, Belleudi F, Ceccarelli S, Bellocci M, Frati L, Torrisi MR, Picardo M: UVBinduced activation and internalization of keratinocyte growth factor receptor. Oncogene 2003;22:24222431.

-41 Finch PW, Murphy F, Cardinale I, Krueger JG: Altered expression of keratinocyte growth factor and its receptor in psoriasis. Am J Pathol 1997;151:1619-1628.

-42 Zhou Y, Lee HS, Kooshesh F, Fujisawa H, Sauder DN, Kondo S: Effects of UVB irradiation on keratinocyte growth factor (KGF) and receptor (KGFR) expression in cultured human keratinocytes. Exp Dermatol 1996;5:138-144.

-43 Nathan C, Cunningham-Bussel A: Beyond oxidative stress: an immunologist's guide to reactive oxygen species. Nat Rev Immunol 2013;13:349-361.

44 Dhanasekaran DN, Reddy EP: JNK signaling in apoptosis. Oncogene 2008;27:6245-6251.

-45 Devasagayam TP, Tilak JC, Boloor KK, Sane KS, Ghaskadbi SS, Lele RD: Free radicals and antioxidants in human health: current status and future prospects. J Assoc Physicians India 2004;52:794-804.

46 Auten RL, Davis JM: Oxygen toxicity and reactive oxygen species: the devil is in the details. Pediatr Res 2009;66:121-127.

47 O'Reilly MA, Staversky RJ, Huyck HL, Watkins RH, LoMonaco MB, D'Angio CT, Baggs RB, Maniscalco WM, Pryhuber GS: Bcl-2 family gene expression during severe hyperoxia induced lung injury. Lab Invest 2000;80:1845-1854.

48 Han ES, Muller FL, Perez VI, Qi W, Liang H, Xi L, Fu C, Doyle E, Hickey M, Cornell J: The in vivo gene expression signature of oxidative stress. Physiol Genomics 2008;34:112-126.

49 Barazzone C, Horowitz S, Donati YR, Rodriguez I, Piguet PF: Oxygen toxicity in mouse lung: pathways to cell death. Am J Respir Cell Mol Biol 1998;19:573-581.

-50 O'Reilly MA, Staversky RJ, Stripp BR, Finkelstein JN: Exposure to hyperoxia induces p53 expression in mouse lung epithelium. Am J Respir Cell Mol Biol 1998;18:43-50.

-51 Sakaguchi K, Sakamoto H, Lewis MS, Anderson CW, Erickson JW, Appella E, Xie D: Phosphorylation of serine 392 stabilizes the tetramer formation of tumor suppressor protein p53. Biochemistry 1997;36:1011710124.

52 Royce SG, Karagiannis TC: Histone deacetylases and their inhibitors: new implications for asthma and chronic respiratory conditions. Curr Opin Allergy Clin Immunol 2014;14:44-48.

-53 Shay KP, Moreau RF, Smith EJ, Smith AR, Hagen TM: Alpha-lipoic acid as a dietary supplement: molecular mechanisms and therapeutic potential. Biochim Biophys Acta 2009;1790:1149-1160.

-54 Dadhania VP, Tripathi DN, Vikram A, Ramarao P, Jena GB: Intervention of alpha-lipoic acid ameliorates methotrexate-induced oxidative stress and genotoxicity: A study in rat intestine. Chem Biol Interact 2010;183:85-97.

-55 Kolgazi M, Jahovic N, Yuksel M, Ercan F, Alican I: Alpha-lipoic acid modulates gut inflammation induced by trinitrobenzene sulfonic acid in rats. J Gastroenterol Hepatol 2007;22:1859-1865. 